\title{
Dental Nurse: Restoration Treatment for Caries in Students of M, Ts. Alhidayah Tamalate Sub District of Makassar Indonesia 2016
}

\author{
Nurhaeni \\ Department of Dental Nursing, Polytechnic of Health Makassar, South Sulawesi, Indonesia \\ Email address: \\ nurhaeni@poltekkes-mks.ac.id \\ To cite this article: \\ Nurhaeni. Dental Nurse: Restoration Treatment for Caries in Students of M, Ts. Alhidayah Tamalate Sub District of Makassar Indonesia \\ 2016. American Journal of Nursing Science. Vol. 6, No. 4, 2017, pp. 280-284. doi: 10.11648/j.ajns.20170604.11
}

Received: April 15, 2017; Accepted: May 15, 2017; Published: June 21, 2017

\begin{abstract}
Dental caries is a dental and oral problem often complained by students and should receive serious attention due to its increasing prevalence. One of the possible treatments for caries is restoration treatment. The purpose of this study was to determine description of caries and requirement for restoration treatment. This study was a descriptive study with Study Cross Sectional approach. The study was performed on students of M.TS Alhidayah Hartaco Indah in Balang Baru Urban Village, Tamalate Sub-District, Makassar. There were 60 samples of students aged 11, 12, 13 and older. Examination of status of requirement for restoration treatment was performed by referring to Treatment Need Index (TNI). The research result showed needs restoration of the surface that is $(42.8 \%)$, restoration of the two surfaces $(32.57 \%)$, three or more surface restoration $24.57 \%$ that the highest required treatment was restoration of one surface $(60.96 \%)$, followed by restoration of two surfaces $(23.91 \%)$ and then restoration of three surfaces or more $(15.13 \%)$.
\end{abstract}

Keywords: Restorations, Treatment, Caries, Students

\section{Introduction}

Children's teeth are foundation for their growth because their milk teeth determine their permanent teeth. If a child has unhealthy teeth, they will have difficulty chewing, leading to growth disorder. So, they often get sick $[1,3,6]$.

Dental caries happens across the world regardless of age, nationality or economic condition. According to studies in European, American, and Asian countries, including Indonesia, $80-95 \%$ children under 18 have dental caries [2, 4]. It should be known that dental caries happens in human and animal. In human living in group primitively, this disease is rarer than in more civilized. The percentage of dental caries increases along with human civilization and only around $5 \%$ population is immune to dental caries So, it's a challenge to dentistry science $[2,5]$. Caries can't be solved with medication only, especially in indonesia where the ration of dentist to population is 1:35.000. Consider dental and oral disease prevention in the society [7]. If caries has existed, possible treatment is restoration treatment. Tooth restoration is a dental treatment procedure to fix or return shape, function, and appearance of damaged tooth $[8,9]$. This treatment procedure is known as dental filling. Generally, the restoration requires repeated visit and placement of temporary filling, so it's more costly for patient $[10,12]$.

\section{Method}

\subsection{Research Design}

An observational research to describe caries and requirement for restoration treatment in students of MTS AlHidayah Hartaco Indah using cross sectional study approach.

\subsection{Research Location and Period}

The study was performed in MTS Al-Hidayah Hartaco Indah in Balang Baru Urban Village, Tamalate Sub-District, Makassar. The research took place on September November 2016. 


\subsection{Population and Sample}

The sampling method was Total Sampling. The sample was students with caries.

\subsection{Data Collection Method}

Data was collected in two ways, i.e.:

a. Primary Data

Primary data is data collected by examination or direct observation of students of MTS Al-Hidayah Hartaco Indah.

b. Secondary Data

Secondary data was data from interviews with patients with caries in MTS Al-Hidayah Hartaco Indah.

\subsection{Research Flowchart}

The flow of the data collection in this study was [13]:

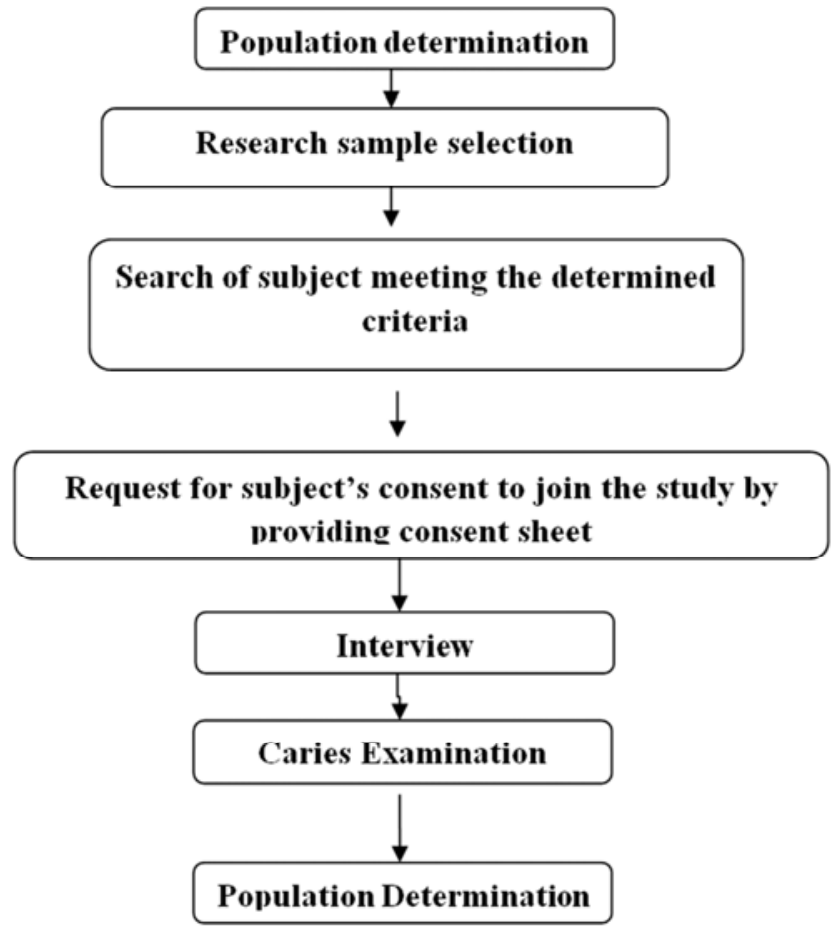

Figure 1. Sample Determination Procedure.

\subsection{Operational Definition}

a. Dental caries is damage of dental hard tissue due to acid in carbohydrate via microorganism insaliva.

b. Restoration or dental filling is to restore lost dental function, integrity and morphology. Loss of structure is usually the result of caries or external trauma. Restoration is required if tooth surface has hole and the selected restoration material can replace its aestheticism and function. The materials include glass ionomer cement.

\subsection{Data Collection Instrument}

The instrument used in this study was observational sheet, which contains:
OHIS index (status card). OHIS is a figure stating the clinical condition of one's mouth, which is found during examination.

\section{Research Result}

The result of the study on dental caries and requirement for restoration treatment in students of MTS Al-Haerat Hartaco Indah in Balang Baru Urban Village, Tamalate Sub-District, is:

Table 1. Frequency Distribution of Classes A \& B in MTS Al-Haerat Tamalate Sub District of Makassar Indonesia 2016.

\begin{tabular}{lll}
\hline Class & Frequency (f) & Percentage (\%) \\
\hline Class A & 30 students & $50 \%$ \\
Class B & 30 students & $50 \%$ \\
Total & 60 students & $100 \%$ \\
\hline
\end{tabular}

Based on table 1 , there were equal numbers of students in each class, i.e. 30 students or $50 \%$ in class $\mathrm{A}$ and 30 students or $50 \%$ in class $\mathrm{B}$.

Table 2. Frequency Distribution of DMF-T Based on Gender.

\begin{tabular}{lllll}
\hline \multirow{2}{*}{ Gender } & Components & & & $\begin{array}{l}\text { Amount of } \\
\text { DMF-T }\end{array}$ \\
\cline { 2 - 4 } & D & M & F & 32 \\
M & 27 & 5 & - & 41 \\
F & 33 & 8 & - & 73 \\
Total & 60 & 13 & - & \\
\hline
\end{tabular}

Shows the index decay occurs in female students is 33 or the total number of DMF-T at 41 and so did the missing index is 8 or overall amount of DMF-T 41, filling occurred on student female gender compared with male patients gender.

Table 3. Frequency Distribution of DMF-T Based on Class Sample.

\begin{tabular}{llllll}
\hline \multirow{3}{*}{ No. } & \multicolumn{3}{l}{ Criteria DMF-T } & \multirow{2}{*}{ Number } \\
\cline { 2 - 5 } & Good & Medium & Low & Poorly & \\
\cline { 2 - 5 } & - & 13 & 5 & 42 & 60 \\
\cline { 3 - 5 } Amount (\%) & - & $21,6 \%$ & $8,4 \%$ & $70 \%$ & $100 \%$ \\
\hline
\end{tabular}

Table 3 above shows the level of dental caries and DMF-T value no student good criteria, the medium 13 students $(21.6 \%)$, low criteria students $(8.4 \%)$, poorly/bad criteria is 42 students $(70 \%)$.

Table 4. Frequency Distribution of Caries Based on Many Surfaces Affected.

\begin{tabular}{lll}
\hline Caries is based on many surfaces exposed & $\mathbf{N}$ & $\mathbf{\%}$ \\
\hline Simple caries & 24 & $40 \%$ \\
Compound caries & 19 & $31,7 \%$ \\
Complex caries & 17 & $28,3 \%$ \\
Total & 60 & $100 \%$ \\
\hline
\end{tabular}

Based on the data shown in Table 4 above shows that the percentage of the 24 dental caries simple (40\%), ie 19 dental caries compound $(31.7 \%)$, and complex dental caries which amounted to $17(28.3 \%)$. 
Table 5. Frequency Distribution Based Care Needs Restoration.

\begin{tabular}{lll}
\hline Care Needs & $\mathbf{N}$ & $\mathbf{\%}$ \\
\hline Need & 60 & $100 \%$ \\
No Need & - & - \\
Total & 60 & $100 \%$ \\
\hline
\end{tabular}

Sourch: Primary Data, 2016

Data shown in Table 5 shows that of the 60 teeth examined contained 60 teeth $(100 \%)$ in need of care. All children in need of care.

Table 6. Frequency Distribution Needs Restoration Treatment Based On Types of Treatment.

\begin{tabular}{lll}
\hline Variety of treatments & $\mathbf{N}$ & $\mathbf{\%}$ \\
\hline Restoration of one surfaces & 24 & $40 \%$ \\
Restoration of two surfaces & 19 & $31,7 \%$ \\
Restoration of three or more surfaces & 17 & $28,3 \%$ \\
Total & 60 & $100 \%$ \\
\hline
\end{tabular}

Sourch: Primary Data, 2016

The above data shows that the highest percentage of care needs restoration on the type of restorative treatment of the tooth surface by 24 elements $(40 \%)$, followed by the restoration of the two surfaces of a tooth element 19 (31.7\%) and the lowest is three or more surface restoration number 17 dental elements $(28.3 \%)$.

Table 7. Frequency Distribution Based on Element Restoration Treatment Need With Dental Caries On Maxilla.

\begin{tabular}{lllllll}
\hline \multirow{2}{*}{ Element Tooth } & \multicolumn{7}{l}{ Treatments Need } & $\mathbf{2}$ & $\mathbf{3}$ & \\
\cline { 2 - 7 } & $\mathbf{1}$ & $\mathbf{0}$ & $\mathbf{n}$ & $\mathbf{\%}$ & $\mathbf{N}$ & $\mathbf{\%}$ \\
\cline { 2 - 7 } & $\mathbf{N}$ & $\mathbf{\%}$ & 6,3 & 2 & $2{ }^{2}$ \\
\hline I1 & 3 & 3,79 & 5 & 2,5 & 2 & $2{ }^{2}$ \\
I2 & 2 & 2,5 & 2 & 2,5 & 3,79 \\
C & 0 & 0 & 1 & 1,26 & 3 & 3,79 \\
P1 & 2 & 2,5 & 2 & 2,5 & 3 & $2,{ }^{2}$ \\
P2 & 6 & 7,59 & 3 & 3,79 & 2 & 11,39 \\
M1 & 8 & 10,1 & 4 & 5,06 & 9 & 3,79 \\
M2 & 9 & 11,39 & 8 & 10,12 & 3 & 30,38 \\
Total & 30 & 37,97 & 25 & 31,64 & 24 & \\
\hline
\end{tabular}

Keterangan 1 = Restoration of one surfaces

$2=$ Restoration of two surfaces

$3=$ Restoration of three or more surfaces

The results in Table 7 show that the need for restorative treatment if sorted by element teeth in the maxilla, then seen the highest percentage in the second molar amount of 9 $(11.39 \%)$, which requires the restoration of the surface, then the first molar amount of $8(10,1 \%)$, the second premolar number $6(7.59 \%)$, the first incisor $3(3.79 \%)$, the first premolar $2(2.5 \%)$, together with the lateral incisor 2 $(2.25 \%)$, and the lowest canine with the number 0 .

Table 8. Frequency Distribution Based on Element Restoration Treatment Need For Dental Caries On Mandible.

\begin{tabular}{lllllll}
\hline \multirow{3}{*}{ Elements Tooth } & \multicolumn{7}{l}{ Treatments Need } \\
\cline { 2 - 7 } & $\mathbf{1}$ & $\mathbf{2}$ & & $\mathbf{3}$ & \\
\cline { 2 - 7 } & $\mathbf{N}$ & $\mathbf{\%}$ & $\mathbf{n}$ & $\mathbf{\%}$ & $\mathbf{N}$ & $\mathbf{\%}$ \\
\hline I1 & 2 & 2,08 & 0 & 0 & 1 & 1,04 \\
I2 & 1 & 1,04 & 0 & 0 & 1 & 1,04 \\
\hline
\end{tabular}

\begin{tabular}{lllllll}
\hline \multirow{2}{*}{ Elements Tooth } & \multicolumn{7}{l}{ Treatments Need } \\
\cline { 2 - 7 } & $\mathbf{1}$ & $\mathbf{2}$ & $\mathbf{3}$ & \\
\cline { 2 - 7 } & $\mathbf{N}$ & $\mathbf{\%}$ & $\mathbf{n}$ & $\mathbf{\%}$ & $\mathbf{N}$ & $\mathbf{\%}$ \\
\hline C & 1 & 1,04 & 1 & 1,04 & 0 & 0 \\
P1 & 2 & 2,08 & 2 & 2,08 & 2 & 2,08 \\
P2 & 3 & 3,12 & 5 & 5,2 & 3 & 3,12 \\
M1 & 13 & 13,54 & 13 & 13,54 & 4 & 4,17 \\
M2 & 23 & 23,95 & 11 & 11,45 & 8 & 8,00 \\
Total & 45 & 48,87 & 32 & 33,4 & 19 & 19,79 \\
\hline
\end{tabular}

Information 1 = Restoration of one surfaces $2=$ Restoration of two surfaces

$3=$ Restoration of three or more surfaces

Based on the results obtained in Table 8 shows that the need for restorative treatment if sorted by the teeth on the mandible element, then the highest percentage seen in the second molar tooth number 23 (23.95\%), which requires the restoration of the surface, then the first molar amount of 13 $(13,54 \%)$, the second premolar number $3(3.12 \%)$, the first incisor and first premolar balanced number $2(2.08 \%)$, and the low of the second incisors and canines number $1(1.04 \%)$.

Table 9. Frequency Distribution of Treatment Need Dental Restorations Based on Tooth Element.

\begin{tabular}{lllll}
\hline \multirow{2}{*}{ Treatments Need } & \multicolumn{3}{l}{ Tooth Element } & \\
\cline { 2 - 5 } & \multicolumn{2}{l}{ Maxilla } & \multicolumn{2}{l}{ Mandubulla } \\
\cline { 2 - 5 } & $\mathbf{N}$ & $\mathbf{\%}$ & $\mathbf{N}$ & $\mathbf{\%}$ \\
\hline Restoration of one surfaces & 30 & 37,97 & 45 & 46,87 \\
Restorasi dua permukaan gigi & 25 & 31,64 & 32 & $33,0 ̈$ \\
Restoration of three or more surfaces & 24 & 30,38 & 19 & 19,79 \\
Total & 79 & 100 & 96 & 100 \\
\hline
\end{tabular}

The data in table 9 shows that the highest percentage of requirement for restoration treatment was in maxillary region with 30 students $(37,97 \%)$ requiring restoration treatment of one surface, then 25 students $(31,64 \%)$ requiring restoration treatment of two surfaces, and finally $24(30,38 \%)$ students requiring restoration treatment of three or more surfaces. The mandibular region wasn't very different from the maxillary region. The highest percentage was treatment of one surface (45 students or $46,87 \%$ ), then restoration treatment of two surfaces (32 students or 33,4\%), and finally restoration of three or more surfaces (19 students or 19,79\%).

\section{Discussion}

The result of the study on students in MTS Al-Haerat showed that the requirement for restoration treatment was $16,92 \%$. The number could be misinterpreted. People may think that the dental and oral health of the respondents were good because the number of damaged teeth requiring treatment was small. However, it didn't show the real condition. The researcher found teeth with caries that couldn't get restoration treatment and were indicated for extraction. There were also dental losses. The dental and oral health of the respondents were shown in the research result on caries by the amount of surfaces with simple caries ( 24 or $40 \%$ ), compound caries (19 or $31,7 \%$ ), complex caries (17 or $28,3 \%)$.

Distribution of the result of the study on requirement for 
restoration treatment by treatment type showed that the highest requirement was restoration treatment of one surface ( 75 or $42,8 \%$ ), then restoration treatment of two surfaces $(57$ or $32,57 \%$ ), and finally restoration treatment of three or more surfaces (43 or $24,57 \%$ ).

It happened because students didn't understand and weren't aware of the importance of maintaining dental and oral health, so the urge to get restoration treatment was very low. There was also no facility and infrastructure for restoration treatment and there was a lack of promotion and preventative action by dental nurses in Tamalate SubDistrict.

The result of the research on requirement for restoration treatment in research subjects by dental element showed that the highest percentage was the second molar ( 9 or 11,39\%) which required restoration of one surface, then the first molar ( 8 or $10,1 \%$ ), the second premolar (6 or $7,59 \%$ ), the first incisor(3 or $3,79 \%$ ), the first premolar ( 2 or $2,5 \%)$, the second incisor( 2 or $2,25 \%$ ), and lastly the canine $(0)$. It's because molar had the most caries and the morphology of molar has pits and fissures. Fissure is formed in groove development and don't fully unit, creating unique depression on email surface. Pit and fissure are also the easiest part to develop caries. Food remains in the area are difficult to clean, so microbes can live and produce acid, which may cause caries.

Moreover, the first molar is also the first tooth to erupt in oral cavity, so it comes in contact with good more often and longer. Meanwhile, canine is located in the anterior, which is more easily reached by toothbrush for cleaning. Moreover, incisor rarely gets caries because there is saliva gland which works directly to clean the incisor or self-cleansing. Teeth that required caries and restoration treatment were in the posterior.

It showed that the students' understanding on maintaining dental and oral health is low, so people tended to clean the teeth in the anterior than teeth in the posterior. People also thought that it's better to maintain anterior teeth than posterior teeth because anterior teeth are necessary for aesthetics [12].

The result of the research on requirement for restoration treatment by jaw region showed that restoration treatment was more required in the mandibular region (96 teeth or $54,8 \%$ ) than the maxillary region (79 teeth or $45,2 \%$ ). It showed that caries often happened in teeth in the mandible. This is because all teeth in the mandible erupt before the teeth in the maxilla, so the risk of caries is higher. In terms of gravity of water flow in the mouth, water flows more easily to the lower part and food remains are more often deposited in the mandible, so if not cleaned in a long time, the risk of caries will increase $[8,14]$.

\section{Conclusions and Recommendations}

\subsection{Conclusion}

Overview caries based on the number of affected surface as follows: 24 simple dental caries (40\%), compound 19 dental caries (31.7\%), complex dental caries 17 (28.3\%). Needs restoration treatment at most that needs restoration of the surface that is $(42.8 \%)$, restoration of the two surfaces $(32.57 \%)$, three or more surface restoration $24.57 \%$. Students are expected to pay more attention to oral health, especially in dealing with caries problems by performing proper maintenance in medication needs and teeth restorations.

\subsection{Recommendations}

For health institutions are expected to improve the health care program appropriate dental caries based on exposed surfaces and maintenance equirements are needed for students. The periodic examination should be performed at least 2 times within one year at the dental clinic or the nearest health center to prevent dental caries $[9,14]$.

\section{References}

[1] Depkes RI, 2004. Petunjuk Pemeliharaan Kesehatan Gigi Dan Mulut Keluarga. Hal 10 Jakarta: Frenken. Jo, Prathip Phantom Vanit, Taco Pilot, Yupin Song Paisan, Event Van Amerongent.

[2] Essentials of Dental Caries, 2nd edition by E. A. M. Kidd and S. Joyston-echal. Published by Oxford University Press, 1997, pp. 214.

[3] Depkes RI, 2008. Petunjuk Pemeliharaan Kesehatan Gigi Dan Mulut. Jakarta.

[4] Eccles \& Green. 1994. Konsevasi gigi. Jakarta: widya medika Erwana. A. F. 2013. Seputar Kesehatan Gigi Dan Mulut. Yogyakarta: Rapha Publishing.

[5] Hongini. S. Y \& Aditiawarman. M. 2012. Kesehatan Gigi Dan Mulut. Bandung.: Pustaka Reka Cipta.

[6] Irma. I. 2013. Penyakit Gigi, Mulut, Dan THT. Yogyakarta: Medical Book Mumpuni. Y \& Pratiwi. E. 2013. 45 Masalah Dan Solusi Penyakit Gigi Dan Mulut. Yogyakarta: Rapha Publishing.

[7] Pratiwi. D. 2009. Gigi Sehat Dan Cantik. Jakarta: Buku Kompas. Rahmadhan. A. G. 2010. Serba Serbi Kesehatan Gigi Dan Mulut. Jakarta: Bukune.

[8] Putri Megananda Hiranya, Herijulianti Eliza, Nurjannah Neneng, 2010. Ilmu Pencegahan Penyakit Jaringan Keras Gigi dan Jaringan Pendukung Gigi. Buku Kedokteran EGC. Jakarta.

[9] NUGROHO, Cahyo. Analisis faktor-faktor yang mempengaruhi minat dokter gigi Kota Tasikmalaya untuk berpartisipasi dalam program dokter gigi keluarga. Diss. Universitas Gadjah Mada, 2010.

[10] Suwargiani A, Anne. 2008. Indeks def-t dan DMF-T Msasyarakat Desa mekarsari Kecamatan Tirtamulya kabupaten Karawang. (Skripsi). Bandung: Fakultas kedokteran gigi. Universitas Padjajaran. 
[11] Taringan. R. 2012. Karies Gigi. Jakarta: Buku Kedokteran EGCWHO. 2006. OHI-S (Simplified) Green and Vermillion 1964. [Serial Online].

http://www.whocollab.od.mah.se/expl/ohisgv.html. [20 maret 2013].

[12] Kartilah, Tetet, et al. "Pengaruh Bersiwak Dengan Menggunakan Alat Bantu Modifikasi Terhadap Kebersihan Gigi dan Mulut Pada Santri di Pondok Pesantren Al-Kautsar Kabupaten Kuningan Jawa Barat Tahun 2016." Actual Research Science Academic 1.1 (2017): 33-41.
[13] WHO. 2006. Caries Prevalence: DMF-T And DMF-S. [serial online]. http:www.whocollab.od.mah.se/expl/ohisgv. Html. [20 maret 2013].

[14] Muhammad Saleh, Nurhaeni, Oke Sainuddin, Syamsuddin Abubakar, Johny Angki, Yayah Sopianah, Hadiyat Miko. Effect Stick of Miswak on Periodontal Reccesion to Jama'ah Tabligh Kerung Kerung Kota Makassar, Indonesia. International Journal of Dental Medicine. Vol. 3, No. 1, 2017 , pp. 1-3. doi: 10.11648/j.ijdm.20170301.11. 